\title{
Organic-Matter Activity of Some Typical Soils of Puerto Rico
}

\author{
Fernando Abruña-Rodríguez and José Vicente-Chandler ${ }^{1}$
}

INTRODUCTION

Although considerable such information is available from Temperate regions, relatively little is known about the activity of organic matter in Tropical soils.

The objectives of the study herein reported were (1) to evaluate the exchange capacity of the organic matter in samples of the most important soils of Puerto Rico by using three different methods, and (2) to determine the exchange capacity of portions of the organic matter variously resistant to oxidation.

\section{MATERIALS AND METHODS}

Surface samples representing the Catalina, Cialitos, Alonso, Los Guineos, Múcara, Jayuya, Utuado, Río Piedras, Coto, Matanzas, and Nipe soil series were used in this study. Roberts $(13)^{2}$ has described these soils in detail. All are kaolinitic with the exception of Múcara the clay minerals of which are mainly of the expanding lattice type (1).

After the soil samples were air-dried, organic matter was determined by the wet-combustion method. A previously determined (14) correction factor of 1.2 was used in the calculation of total carbon from oxidized carbon. Total nitrogen was determined by the Kjeldahl method. PH values were ascertained with a glass electrode potentiometer. Cation-exchange capacities were determined by the ammonium acetate method. The pipette method was used in performing the mechanical analyses.

The exchange capacity of the organic matter was evaluated by three different methods as follows:

\section{THE "DIFFERENCE" METHOD}

The organic-matter content and the cation-exchange capacity of the soil samples were determined before and after destruction of most of the organic matter with hydrogen peroxide. The reduction in exchange capacity was assumed to be due to the loss of organic matter. From these data the exchange capacity of the organic matter was calculated.

1 Soil Scientist and Superintendent of the Cooperative ARS Research Project, respectively, Agricultural Experiment Station, University of Puerto Rico, Río Piedras, P. R.

${ }^{2}$ Numbers in parentheses refer to Literature Cited, pp. 75-6. 


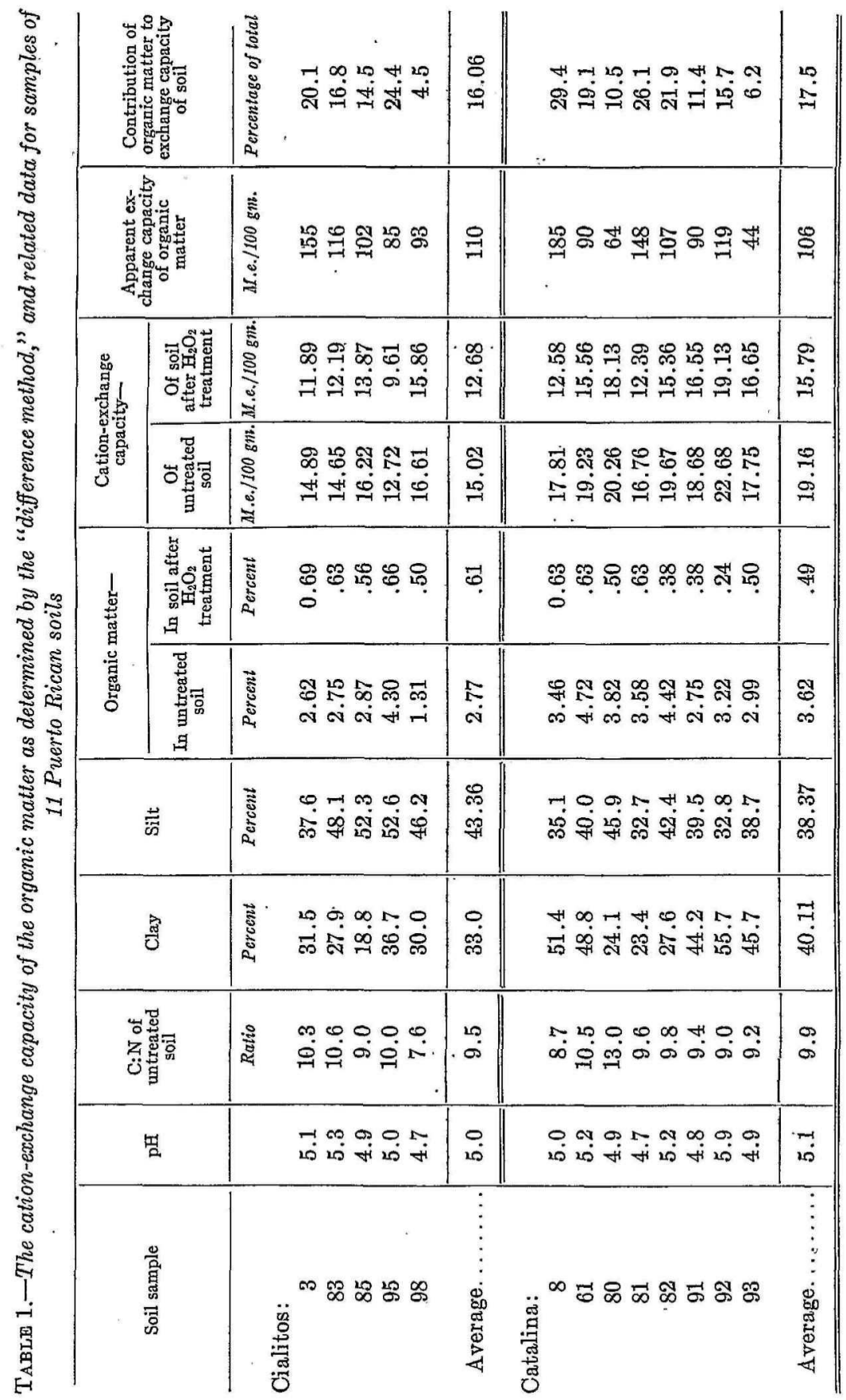




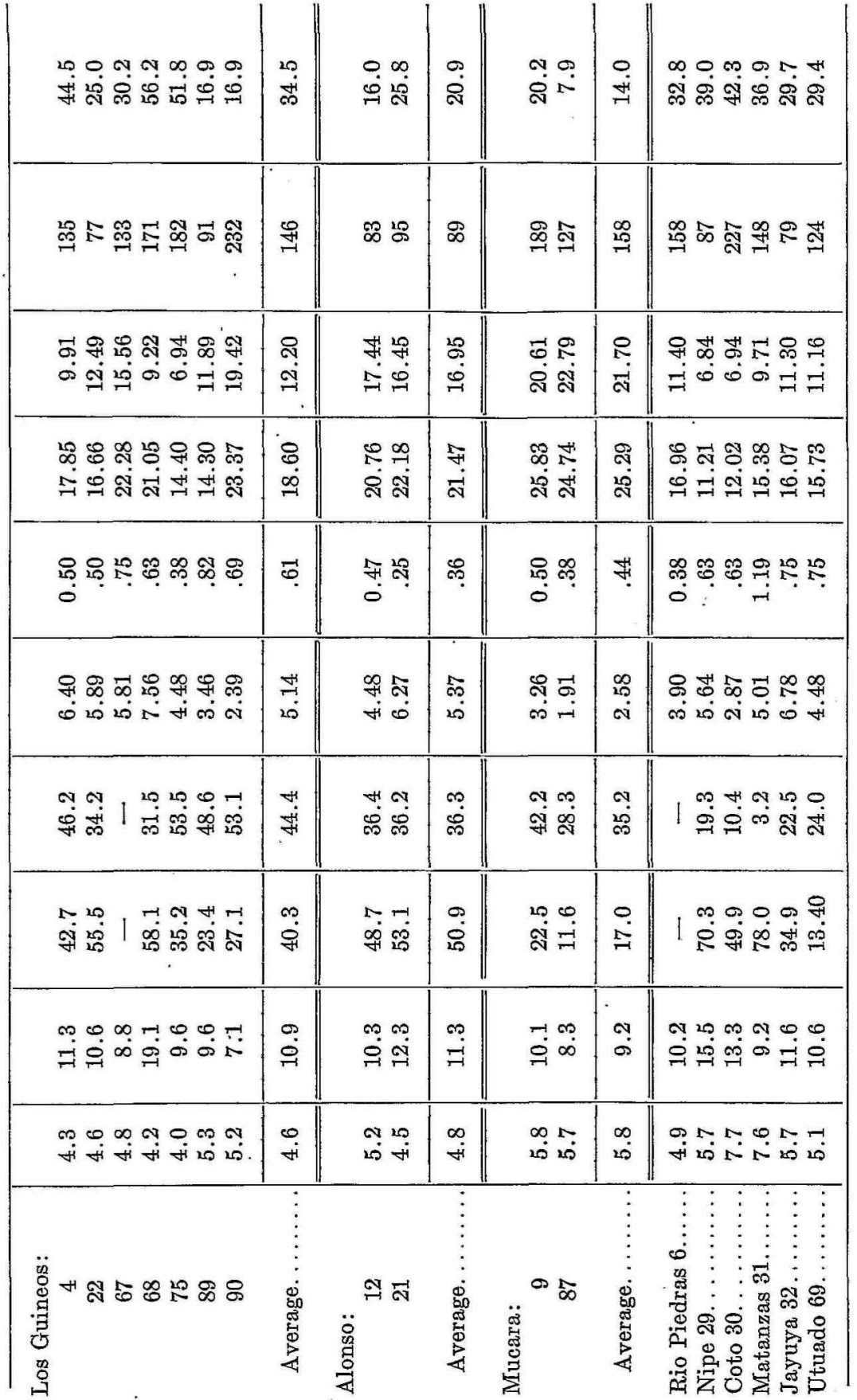




\section{TITRATION OF EXTRACTED ORGANIC MATTER}

The organic matter of selected samples was extracted following the procedure used by Marshall and Patnaik (6), with only minor modifications. The procedure used was as follows: $200 \mathrm{gm}$. of air-dry soil were shaken with 2 l. of $0.02 \mathrm{~N} \mathrm{HCl}$. After standing overnight, the supernatant liquid was siphoned off and the soil washed with distilled water until free of chlorides. The residue was then shaken with $2 \mathrm{I}$. of $0.5 \mathrm{~N} \mathrm{Na}_{2} \mathrm{CO}_{3}$ solution and left overnight. The dissolved material was siphoned off and transferred to a jar with 11 . of 5 -percent $\mathrm{NaCl}$ solution to flocculate any suspended inorganic material. After standing 8 hours the dark-colored solution was siphoned off, filtered, and then slowly: acidified with dilute HCl. The organic matter precipitated by the acid was then centrifuged and freed from the supernatant liquid. It was again dissolved in $\mathrm{Na}_{2} \mathrm{CO}_{3}$ and precipitated as before. Finally, the flocculent precipitate was washed with distilled water until free of soluble salts. An organic-matter suspension was obtained by dispersing the material in distilled water.

The exchange capacity of the extracted organic matter was determined by titration in aqueous solution with calcium hydroxide. Nine days were allowed for the reaction to be completed. As the organic material was easily dispersed in water; concentration was determined by evaporating a known volume of liquid at $105^{\circ} \mathrm{C}$. and weighing the residue.

\section{CORRELATION BETWEEN EXCHANGE CAPACITY AND}

ORGANIC-MATTER CONTENT

The cation-exchange capacity and organic-matter content of samples from two similar soils (Coto and Catalina) were determined. These values were also determined for samples taken at varying depths in a Catalina soil. The exchange capacity of the organic matter was estimated from the relationship existing between the organic-matter content and the total exchange capacity of the soil samples.

The exchange capacity of the organic matter which could be separated from two samples of Catalina soil by flotation was determined. This fraction of the organic matter was obtained by placing the oven-dry soil in a beaker of water and removing all the organie matter which floated on the surface.

Subsamples from these two soil samples were treated with different concentrations of hydrogen peroxide over different time intervals. It was assumed that with this treatment portions of the organic matter with varying resistance to oxidation, were destroyed. Organic-matter and exchange-capacity determinations were made on the samples before and after treatment with hydrogen peroxide. From these data the exchange capacity of the various portions of the organic matter was calculated. 


\section{RESULTS}

Analytical data for the soil samples studied are shown in table 1. The range of organic matter-values and $\mathrm{C}: \mathrm{N}$ ratios was about normal for these soils (14). All the samples were acid with the exception of those from the Coto and Matanzas soil series. These soils were derived from limestone and,

TABLE 2.-Anilysis of the organic matter extracted from samples of 4 typical soils of Puerto Rico

\begin{tabular}{|c|c|c|c|c|c|c|}
\hline \multicolumn{2}{|c|}{ Soil samples } & \multirow{2}{*}{$\begin{array}{l}\text { Cation- } \\
\text { exchange } \\
\text { capacity }\end{array}$} & \multirow{2}{*}{ Ash } & \multirow{2}{*}{ Nitrogen } & \multirow{2}{*}{$\begin{array}{c}\text { Carbon } \\
:\end{array}$} & \multirow{2}{*}{ C:N Ratio } \\
\hline Soil & Number: & & & & & \\
\hline & $\cdots$ & MF.e. $/ 100 \mathrm{gms}$. & Percent & Percent & - Perceni & \\
\hline Cialitos & 3 & 180 & 1.19 & 4.02 & 52.24 & 13.0 \\
\hline Catalina & 8 & 220 & 1.53 & 5.01 & 50.85 & 10.1 \\
\hline Do. & 61 & 200 & 1.62 & 5.17 & 50.40 & 9.7 \\
\hline Los Guineos & . 4 & 238 & 3.64 & 4.80 & 58.71 & 12.2 \\
\hline Do. & 22 & .220 & 3.22 & 5.41 & 56.20 & 10.4 \\
\hline Alonso & 12 & 260 & 2.32 & 4.05 & 50.06 & 12.4 \\
\hline Do. & $\therefore 21$ & 290 & 2.44 & 4.32 & $\cdot 50.61$ & 11.7 . \\
\hline
\end{tabular}

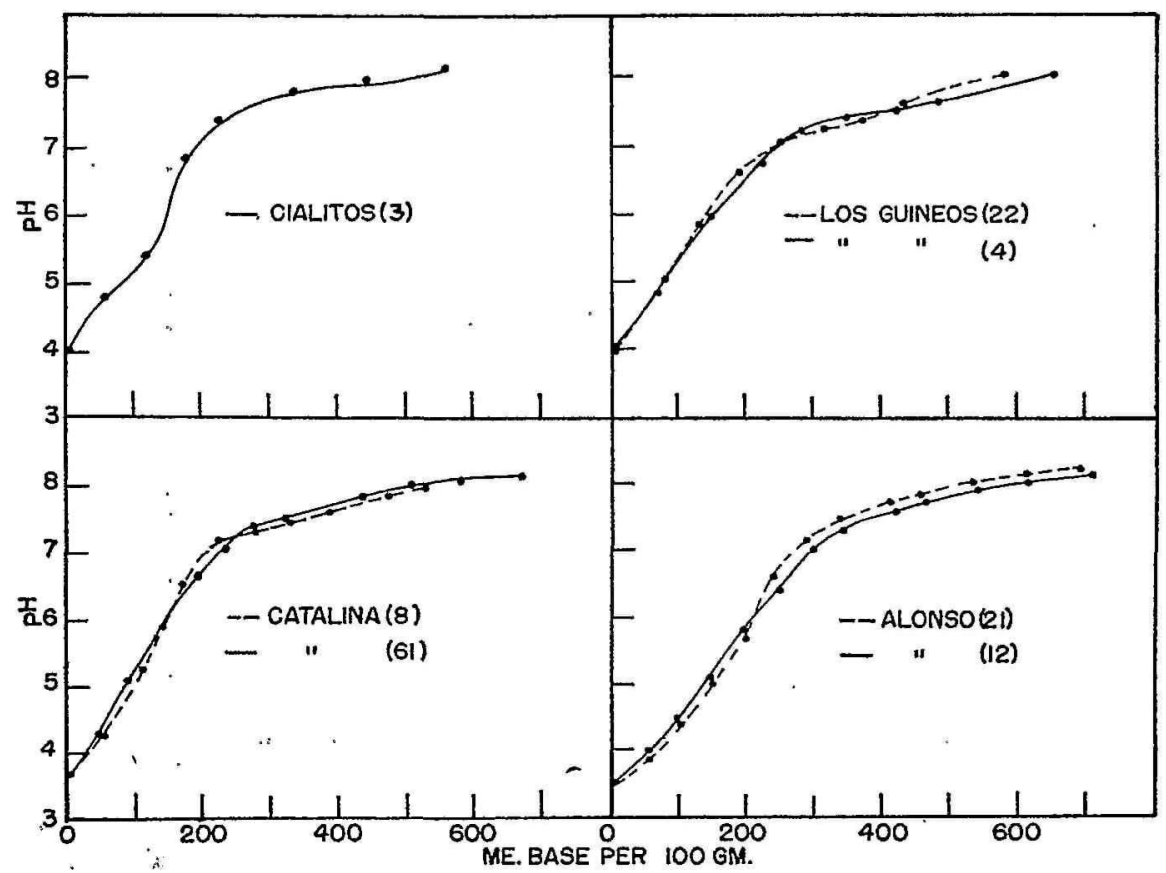

FrG. 1.-Titration curves of organic matter extracted from samples of 4 typical soils of Puerto Rico. 


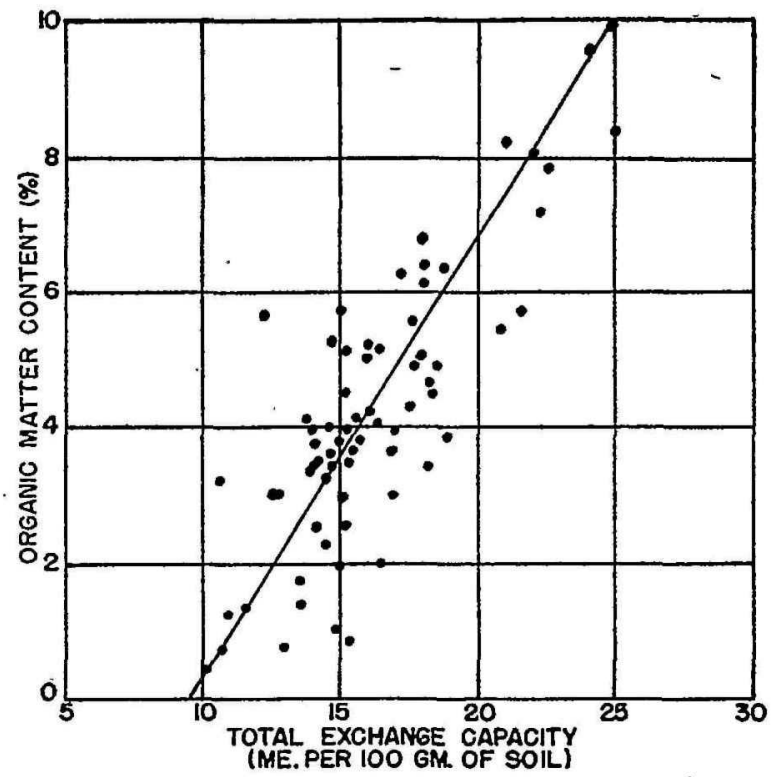

Fig. 2.-The activity of soil organic matter as indicated by the relationship between exchange capacity and organic-matter content of 73 samples of 2 kaolinitic clay soils-Catalina and Coto. Each $100 \mathrm{gm}$. of organic matter appears to have an average exchange capacity of about $150 \mathrm{~m}$.e.

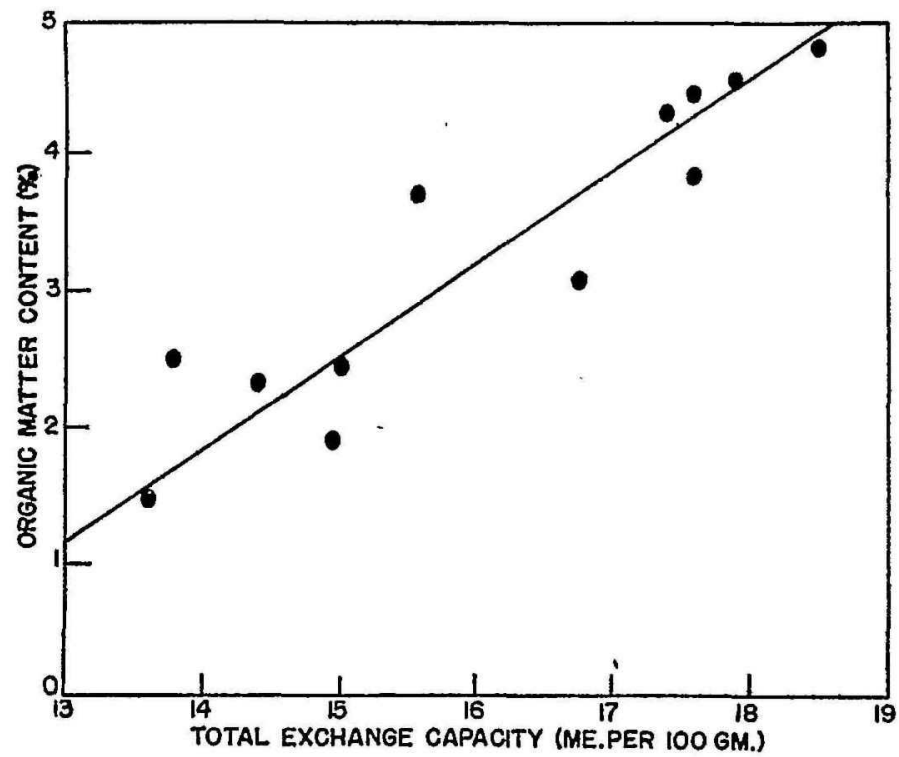

Frg. 3.-The activity of soil organic matter as indicated by the relationship between exchange capacity and organic-matter content of samples of a Catalina clay soil taken at different depths. Each $100 \mathrm{gm}$. of organic matter appears to have an average exchange eapacity of about $138 \mathrm{~m}$.e. 
though normally acid, there are areas where the soils are neutral to alkaline due to the influence of marley exposures of the parent material.

The results of the study to determine organic-matter activity by the difference method are summarized in table 1 . The organic matter accounted for from 4.5 to 56.2 percent of the exchange capacity of these soils (average $=24.7$ percent). The apparent cation-exchange capacity of the organic matter varied rather widely, from 44 to 232 (average = about 125) m.e./100 $\mathrm{gm}$. of organic matter. Most of the values, however, were within the range of from 80 to 160 m.e./100 gm. of organic matter.

The cation-exchange-capacity values of the extracted organic matter are given in table 2 . The values obtained by this method were in all cases

TABLE 3.-The apparent exchange capacity of organic-matter fractions variously resistant to oxidation with hydrogen peroxide ${ }^{1}$

\begin{tabular}{|c|c|c|c|c|c|}
\hline Sample and treatment & Nitrogen & $\mathrm{C}: \mathrm{N}$ ratio & $\begin{array}{l}\text { Organic } \\
\text { matter }\end{array}$ & $\begin{array}{c}\text { Cation-ex- } \\
\text { change ca- } \\
\text { pacity of soil }\end{array}$ & $\begin{array}{l}\text { Apparent-cation } \\
\text { exchange capacity of } \\
\text { organic matter }\end{array}$ \\
\hline - & Percent & & Percent & M.e. $/ 100 \mathrm{gm}$. & Mr.e. $/ 100 \mathrm{gm}$. \\
\hline Sample 254: & & & & & \\
\hline 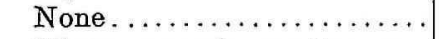 & 0.34 & 11.6 & 6.79 & 18.03 & - \\
\hline $\begin{array}{l}\text { Minus organic matter re- } \\
\text { moved by flotation......... }\end{array}$ & .28 & 11.6 & 5.58 & 13.09 & 408 \\
\hline 15 -percent $\mathrm{H}_{2} \mathrm{O}_{2}$ for $1 \mathrm{hr} \ldots \ldots$ & .17 & 11.0 & 3.23 & 8.15 & 210 \\
\hline 15 -percent $\mathrm{H}_{2} \mathrm{O}_{2}$ for $2 \mathrm{hr} \ldots \ldots$ & .13 & 11.0 & 2.48 & 6.87 & 157 \\
\hline 15-percent $\mathrm{H}_{2} \mathrm{O}_{2}$ for $4 \mathrm{hr} \ldots \ldots$ & .11 & 11.1 & 2.11 & 6.87 & 0 \\
\hline 30 -percent $\mathrm{H}_{2} \mathrm{O}_{2}$ for $4 \mathrm{hr} \ldots \ldots$ & .06 & 12.0 & 1.24 & 6.00 & 100 \\
\hline 30 -percent $\mathrm{H}_{2} \mathrm{O}_{2}$ for $6 \mathrm{hr} . \ldots$ & .06 & 9.5 & .99 & 6.52 & 0 \\
\hline 30 -percent $\mathrm{H}_{2} \mathrm{O}_{2}$ overnight... & .05 & 7.2 & .62 & 6.51 & 0 \\
\hline $\begin{array}{l}\text { Average for all organic matter } \\
\text { destroyed................ }\end{array}$ & , & & & & 187 \\
\hline Sample 256: & & & & & \\
\hline None...................... & 0.38 & 12.5 & 8.17 & 21.03 & 二 \\
\hline $\begin{array}{l}\text { Minus organic matter re- } \\
\text { moved by flotation......... }\end{array}$ & .33 & 12.0 & 6.83 & 15.02 & 448 \\
\hline 15 -percent $\mathrm{H}_{2} \mathrm{O}_{2}$ for $1 \mathrm{hr} \ldots \ldots$ & .26 & 11.1 & 4.96 & 12.44 & 138 \\
\hline 15-percent $\mathrm{H}_{2} \mathrm{O}_{2}$ for $2 \mathrm{hr} \ldots .$. & .23 & 10.9 & 4.34 & 10.94 & 242 \\
\hline 15 -percent $\mathrm{H}_{2} \mathrm{O}_{2}$ for $4 \mathrm{hr} \ldots \ldots$ & .17 & 11.0 & 3.23 & 9.23 & 154 \\
\hline 30 -percent $\mathrm{H}_{2} \mathrm{O}_{2}$ for $4 \mathrm{hr} . \ldots$. & .14 & 10.3 & 2.48 & 8.14 & 145 \\
\hline 30 -percent $\mathrm{H}_{2} \mathrm{O}_{2}$ for $6 \mathrm{hr} . \ldots$. & .05 & 10.1 & .87 & 8.80 & 0 \\
\hline 30-percent $\mathrm{H}_{2} \mathrm{O}_{2}$ overnight... & .05 & 7.2 & .62 & 8.74 & 0 \\
\hline $\begin{array}{l}\text { Average for all organic matter } \\
\text { destroyed................. }\end{array}$ & & & & & 162 \\
\hline
\end{tabular}

${ }^{1}$ Both samples are of Catalina soil with a clay content (kaolinitic) of about 50 percent and a $\mathrm{pH}$ of 4.6 . 
much higher than those obtained by the difference method. They ranged from 180 to 290 (average $=230$ ) m.e. $/ 100 \mathrm{gm}$. of organic matter.

The titration curves for the extracted organic matter are shown in figure 1. All the curves show a high buffer capacity above $\mathrm{pH}$ 7. The curvés for all samples are similar, the main difference lying in their neutralization capacities.

Figure 2 shows the relationship between the exchange capacity and the organic-matter content of 73 samples of Coto and Catalina soils taken from several widely varying locations, These data indicate that the exchange capacity of the soil organic matter a,veraged about 150 m.e./100 gm. of organic matter.

Figure 3 shows the relationship between the exchange capacity and the organic-matter content of samples of Catalina soil taken at different depths at the same location. These data indicate that the exchange capacity of the organic matter averaged about $138 \mathrm{m.e} . / 100 \mathrm{gm}$. of organic matter.

The results of the study to determine the exchange capacity of various portions of the organic matter of two soil samples are given in table 3 . With both samples the organic matter removed by flotation had an extremely high exchange capacity (over $400 \mathrm{~m} . e . / 100 \mathrm{gm}$. of organic matter). The final fractions of organic matter, i.e. those which were most resistant to oxidation, had no apparent exchange capacity. Within these extremes the data seem to indicate that, in general, the portions of organic matter which were most readily oxidized were the most active.

\section{DISCUSSION OF RESULTS}

Most of the soil samples studied had $\mathrm{C}: \mathrm{N}$ ratios of about 10:1, indicating that the organic matter was well decomposed: There was no apparent relationship between soil $\mathrm{pH}$ and the exchange capacity of the organic matter.

The variations in the exchange capacity of the organic matter of the various samples as determined by the difference method were generally in line with the findings of Olson and Bray (11) and of Mitchell (8) who found values ranging from 34 to 283 and from 70 to 200 m.e./100 gm. of organic matter, respectively, with soils of. the United States. Ayers (2) reported an average exchange capacity of $200 \mathrm{~m} . \mathrm{e} . / 100 \mathrm{gm}$. for the organic fraction of latosols from Hawaii, and Craig (4) reported even higher values for a group of soils from Mauritius.

The much higher exchange values obtained by titrating the extracted organic matter are in line with the results of almost all researches on this subject. It may be that only the more active portions of the organic matter were extracted. The similarity between the $C: N$ ratios of the extracted organic matter and those of the normal soil, however, would tend to indicate that a representative portion of the organic matter was extracted. As 
noted by McGeorge (7) the exchange capacity of extracted organic matter depends largely upon the method of extraction used, so any results obtained with this procedure are of doubtful validity.

The ash content of the organic matter has little meaning since. there is no way of determinign what part came from inorganic colloids not properly separated from the organic matter, or from inorganic-organic complexes which actually formed part of the organic matter.

The high buffer capacity of the extracted organic matter above $\mathrm{pH} 7$ is in line with the findings of Baver (3). The formation of insoluble calcium humates may have-something to do with this characteristic as pointed out by Puri (12).

Despite wide variability, the estimated exchange values obtained from the relationship between organic-matter content and the total cation-exchange capacity of the soil samples, are generally of the same order of magnitude as the values obtained by the difference method. The former method, though obviously impractical, would appear to give the most reliable information since the analyses are performed on untreated soil samples. The general agreement found between both methods would seem to lend validity to the difference method for routine laboratory determinations of the exchange capacity of the organic fraction of soils.

The high exchange capacity of the organic matter removed by flotation is of practical importance. Obviously, this material is easily removed by water and even a small run-off could carry away important quantities of this organic fraction, thus considerably reducing the exchange capacity of the soil.

That the more readily oxidizable portion of the organic matter appears to be the most active is also of practical importance. When the soil is exposed, this part of the organic matter is probably oxidized at a relatively high rate, the less active portion remaining in the soil. Adequate soil cover thus appears to be essential to the conservation of this part of the organic matter in view of the very high temperatures attained by exposed surface soils (16).

The data presented in table 3 indicate that the portion of organic matter most resistant to oxidation has no apparent exchange capacity. This is in agreement with the findings of Olson and Bray (11), except that a higher proportion of the organic matter of Puerto Rican soils is apparently in this category. The exchange capacity of the soil in some cases appears to increase following destruction of this portion of the organic matter. These findings suggest a blocking of exchange positions on the clay colloids by the organic matter. The difficulty of destroying this portion of the organic matter likewise points to a close tie-in between clay colloids and soil organic matter. 
This fraction of the organic matter is relatively high in nitrogen as indicated by narrow $\mathrm{C}: \mathrm{N}$ ratios. This suggests that clay-protein complexes of the type described by Norman (10) may be active in binding the clay and organic fractions. Ensminger and Gieseking (5) found that proteins can be strongly absorbed by bentonite through the basic groups acting as exchangeable bases. It is of interest to note that Myers (9) found that the association of clay and organic matter is most likely to occur with large exposed surfaces and under acid conditions such as those occurring with most of the soils studied. The large surface areas of the clay fraction of these soils are indicated by their high wilting points (1) and by their ability to orient or "pack" water molecules (15).

The strong resistance to oxidation of a considerable portion of the organic matter helps to explain the relatively high organic-matter contents of even continuously clean-cultivated soils in Puerto Rico.

\section{SUMMARY}

The exchange capacity of the organic matter in typical soils of Puerto Rico was evaluated from: (1) The variation in the exchange capacity of soil samples following destruction of the organic matter, (2) titration curves of extracted organic matter, (3) and the correlations between exchange capacity and organic-matter content of soil samples. The first method was the most practical and gave fairly accurate results. The second method gave results which were in all cases too high. The third method, though probably the most accurate, is impractical. Results obtained with the first and third methods were similar.

The exchange capacity of the organic matter varied rather widely, but was generally between 100 and $150 \mathrm{~m}$.e. per $100 \mathrm{gm}$. On the average it accounted for about 25 percent of the total exchange capacity of the soils studied.

The organic matter removed by flotation had the highest exchange capacity and the more readily oxidizable portions generally appeared to be the most active. This suggests the importance of conserving the more readily lost portions of the soil organic matter.

A considerable portion of the soil organic matter was extremely resistant to oxidation, had a narrow $\mathrm{C}: \mathbb{N}$ ratio, and apparently little exchange capacity. This suggests a close association between the organic matter and the inorganic soil colloids. The marked resistance to oxidation of a considerable portion of the organic matter may partly explain the high contents found even in continuously cultivated soils in Puerto Rico.

\section{RESUMEN}

Se determinó la capacidad de cambio de la materia orgánica de un grupo de suelos típicos de Puerto Rico usando tres métodos de análisis: (1) Varia- 
ción en la capacidad de cambio de las muestras de suelo al destruirse la materia orgánica. (2) Titulación potenciométrica de los coloides orgánicos extraídos del suelo con carbonato de sodio. (3) Correlación èntre el contenido de materia orgánica y la capacidad de cambio de un grupo considerable de muestras de suelos similares. El primer método resultó ser el más práctico y fácil de llevar a cabo. Dió resultados muy parecidos a los obtenidos usando el método de correlación que es probablemente el más preciso. Este último método es; sinembargo, poco práctico. El segundo método dió los resultados más altos.

La capacidad de cambio de la materia orgánica en las distintas muestras varió considerablemente, estando. la mayoría entre 100 y 150 m.e./100 gramos. Los resultados demostraron que la materia orgánica contribuye alrededor de un 25 por ciento de la capacidad de cambio total en los suelos estudiados.

Se demostró que la fracción de la materia orgánica que se puede separar por medio de la flotación en agua, tiene una capacidad de cambio mayor que ninguna otra porción. Igualmente, la fracción mas propensa a la oxidación mostró una capacidad de cambio mayor que las fracciones más resistentes.

Aparentemente, una parte considerable de la materia orgánica de los suelos de Puerto Rico está combinada íntimamente con la porción mineral y contribuye muy poco a la capacidad de cambio total del suelo. Esta fracción orgánica es muy resistente a la oxidación y esto explica el alto contenido 'de materia orgánica aún en suelos cultivados contínua e intensivamente.

\section{LITERATURE CITED}

1. Abruña, Fernando, and Smith, R. M., Clay mineral types and related soil properties in Puerto Rico, Soil Sci. 75 411-19, 1953.

2. Ayers A. S., Soils of high-rainfall areas in the Hawaiian Islands, Hawaii Univ., Tec. Bul. 1; 1943.

3. Baver, L. D., The effect of organic matter upon several physical properties of soils, J. Amer. Soc. Agron, 22 703-08, 1930.

4. Craig, W., Base exchange relationships in Mauritius soil, Mauritius Dept. Agron. Sugarcane Res. Sta. Bui. 9, 25 pp., 1935.

5. Ensminger, L. E., and Gieseking, J. E., The absorption of proteins by montmorillonitic clays, Soil Sci. No. 48 p. 467, 1939.

6. Marshall, C. E., and Patnaik, N., Ionization of soils and soil colloids: IV Humic and hymatomelanic acids and their salts, Soil Sci. 75 153-65, 1952.

7. McGeorge, W. T., Organic compounds associated with base exchange reactions in soils, Univ. of Ariz. Tech. Bul. No. 31, 1931.

8. Mitchell, J., The origin, nature, and importance of soil organic constituents having base exchange properties, J. Am. Soc. Agron. 24 256-74, 1932.

9. Myers, H. E., Physicochemical relations between organic and inorganic colloids as related to aggregate formation, Soil. Sci. $44331-60,1937$.

10. Norman, A. G., Problems in the chemistry of soil organic matter, Soil Sci. Soc. Am. Proc. (1942) 7 7-15, 1943. 
11. Olson, L. C., and Bray, R. H., The determination of the organic base exchange capacity of soils, Soil Sci. 45 483-95, 1938.

12. Puri, A. N., and Sarup, A., Studies in soil humus: II Potentometric study of the formation of humic acid and humates, Soil Sci. 45 165-74, 1938.

13. Roberts, R. C., Soil survey of Puerto Rico, U.S.D.A. Series 1936, No. 8, Jan. 1942.

14. Smith, R. M., Samuels, G., and Cernuda, C. F., Distribution, conservation and build-up of organic matter and nitrogen in soil profiles of Puerto Rico, Soil. Sci. 72 409-27, 1951.

15. Vicente, José, Domby, C. W., Silva, S., and Figarella, J., Some limitations in the use of the air picnometer, unpublished manuscript, ARS.

16. Vicente, José, Mulches: An important item in tropical agriculture, $J$. Soil \& Water Consv. 8 (3) 136, 1953. 